\title{
Correction to: Sedimentary records of Marine Isotopic Stage 3 (MIS 3) in southern Brazil
}

\author{
Sergio R. Dillenburg ${ }^{1} \cdot$ Eduardo G. Barboza $^{1,2} \cdot$ Maria Luiza C. C. Rosa ${ }^{1} \cdot$ Felipe Caron $^{2} \cdot$ Rodrigo Cancelli $^{3}$. \\ Cristiane B. Santos-Fischer ${ }^{3} \cdot$ Renato P. Lopes $^{4} \cdot$ Matias do Nascimento Ritter $^{2}$
}

Published online: 1 July 2019

(C) Springer-Verlag GmbH Germany, part of Springer Nature 2019

\section{Correction to: Geo-Marine Letters https://doi.org/10.1007/s00367-019-00574-2}

The original version of this article unfortunately contained a mistake.

The presentation of Fig. 1 was incorrect - the rectangle that delimited the study area and the North symbol. The corrected figure is given below.

The original article has been corrected.

The online version of the original article can be found at https://doi.org/ 10.1007/s00367-019-00574-2

Sergio R. Dillenburg

sergio.dillenburg@ufrgs.br

1 Instituto de Geociências, Centro de Estudos de Geologia Costeira e Oceânica, Universidade Federal do Rio Grande do Sul, Porto

Alegre, RS, Brazil

2 Campus do Litoral, Centro de Estudos Costeiros, Limnológicos e Marinhos, Universidade Federal do Rio Grande do Sul, Tramandaí, RS, Brazil

3 Instituto de Geociências, Programa de Pós-Graduação em Geociências, Universidade Federal do Rio Grande do Sul, Porto Alegre, RS, Brazil

4 Laboratório de Oceanografia Costeira, Universidade Federal de Santa Catarina, Florianópolis, SC, Brazil 
Fig. 1 ESRI ${ }^{\circledR}$ Basemap with general and specific location of study sites

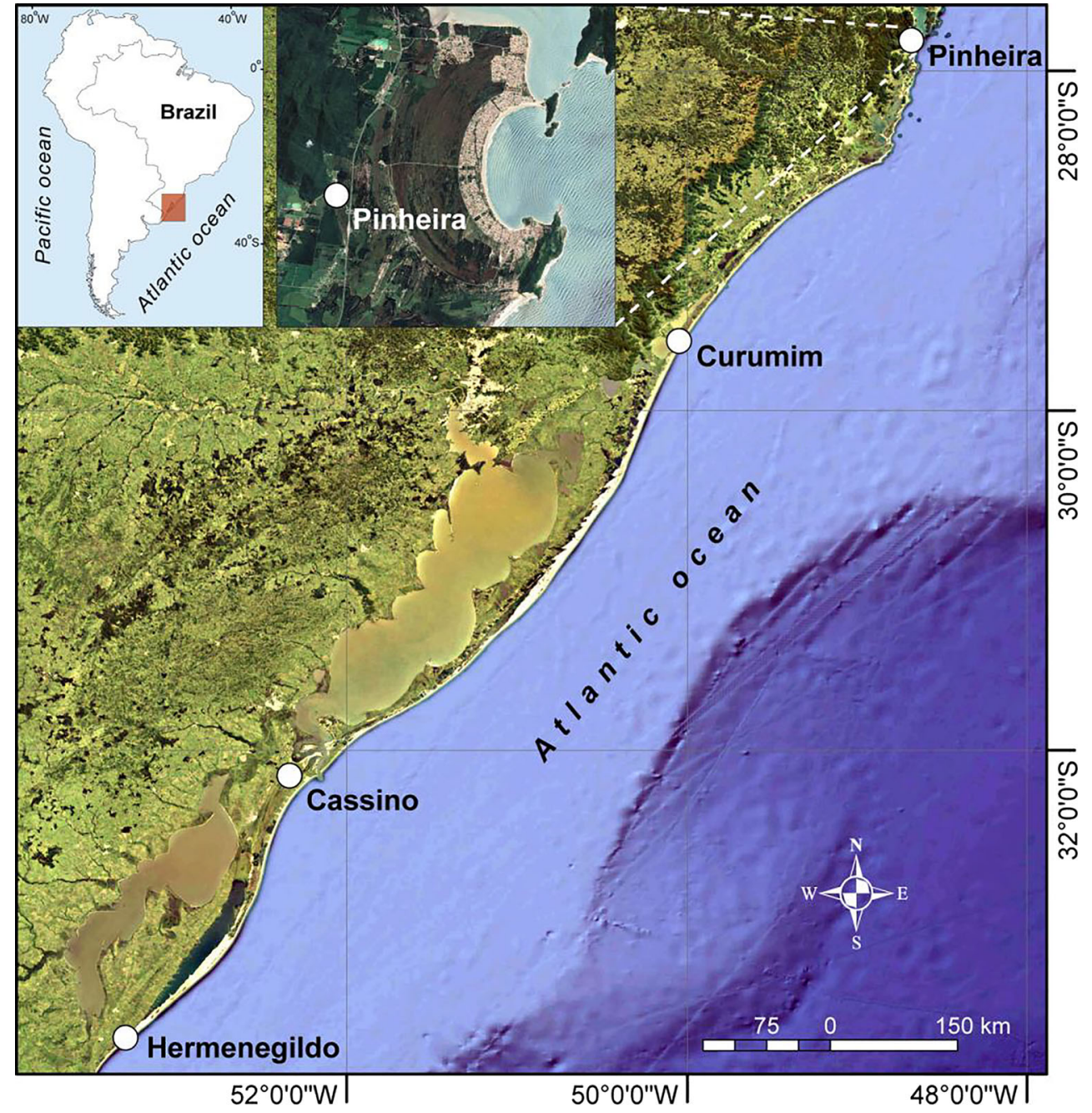

Publisher's note Springer Nature remains neutral with regard to jurisdictional claims in published maps and institutional affiliations. 